\title{
Development of foreign languages teaching tools in agricultural institutes of higher education of Ukraine (the second half of the XX century)
}

\author{
L. M. Khomenko \\ Sumy national agrarian university, Sumy, Ukraine \\ Corresponding author. E-mail: lidiia.khomenko@gmail.com
}

Paper received 24.04.19; Accepted for publication 06.05.19.

\begin{abstract}
https://doi.org/10.31174/SEND-PP2019-197VII79-07
\end{abstract}
\begin{abstract}
The article deals with means of teaching foreign languages applied in agricultural institutes of higher education of Ukraine in the second half of the twentieth century. The use of scientific heuristic and general scientific methods made it possible to classify the foreign languages teaching tools according to the ways of information perception. We have divided them into visual, auditory and visual-auditory groups and highlighted the specifics of development of each one during the researched period.

Keywords: teaching tools, foreign language education, agricultural institutes of higher education.
\end{abstract}

Introduction. The effectiveness of students' mastering foreign languages largely depends on teaching aids which ensure practical implementation of the goal as well as the content of foreign language education. The analysis of the system of foreign language training of students shows that teaching continues to be built on the basis of traditional methods without taking modern information technologies into account. There is an urgent necessity to update and improve the methods of using foreign languages teaching tools at all levels of education. In this regard, the need for studying the previous teaching experience has become topical. Herein, the 50-90-ies of the XX century arouse a considerable scientific interest. It was during this period that dynamic changes took place in the organizational and methodological foundations of foreign language education in institutes of higher education.

A brief overview of publications on the topic. Such scholars as V. Bespalko, N. Burynska, D. Zuiev, S.Trubacheva, A. Syrotenko, V. Tsetlin and others studied the importance of text-based teaching tools for solving educational problems. The possibilities of using technical means of teaching in educational activities are disclosed in the works of N. Anisimova, M. Zhaldak, I. Zakharova, O. Meniailenko, Yu. Zhuk, R.Gurevych, O. Bashmakov, P. Obraztsov and others. However, the peculiarities of the use of teaching tools in mastering foreign languages by students of non-language specialties have not yet become the subject of a special study.

The purpose of the article is to characterize the peculiarities of the development of foreign languages teaching tools in agricultural institutes of higher education of Ukraine in the second half of the twentieth century.

Materials and methods. Materials of state archives of Ukraine and educational literature of the period under study were systematized, analyzed and summarized using scientific heuristic and general scientific methods.

Results and discussion. By teaching tools we mean material objects that contribute to the organization, increase of effectiveness and achievement of the goal of foreign language education in institutes of higher education of agrarian profile. According to the method of perception of information, they can be divided into visual, auditory and visual-auditory.

Visual means of teaching foreign languages included text and figurative objects. In the conditions of a hard state monopoly on educational literature, primarily due to ideological factors, a textbook kept to be the main text- based learning tool in the early 1950s. Most of the agricultural institutes of Ukraine had a sufficient number of copies of textbooks and manuals by that time. Thus, Kyiv Veterinary Institute in the 1953 - 1954 academic year had 90 textbooks in the Latin language, 205 textbooks and 350 methodological manuals in German, 170 textbooks and 175 English language manuals available. [6, p.45].

However, these educational books with general content were compiled for all non-linguistic specialties (except for the textbook by B. Mazikov on the Latin language for higher veterinary educational institutions). Due to the lack of professional texts and terms in them, they did not contribute to the training of agricultural specialists. For example, in the German language manual, compiled by a group of philologists from the GDR, the texts were "of cognitive value, reflecting Soviet reality and showing Soviet cultural and economic construction, the achievements of Russian and Soviet science, the heroics of labor of the Soviet people, their exploits on the front and struggle for peace all over the world." The authors also offered texts about the underground struggle of German anti-fascists against Hitlerism. [3, p.3].

Teachers of foreign languages of agricultural institutes of higher education attempted to overcome the aforementioned disadvantages of general textbooks using other text-based teaching aids. Thus, the department of foreign languages of Kharkiv Institute of Mechanization and Electrification of Agriculture in 1951 compiled a collection of technical articles for optional classes [7, p. 75]. The library fund of Bilotserkivskyi Agricultural Institute in the early 1950 s was actively replenished with foreign publications. The library purchased 175 journals and 4 books published abroad to be used in the educational process. [5, p.126].

There was a shortage of specialized text-based teaching tools at the correspondence departments of agricultural institutes. Manuals for examinations used in the educational process did not correspond to the type of specialization. The departments of foreign languages of agricultural institutions were forced to prepare their own teaching materials for all types of education including extra-mural courses. [16, p.193].

The resolution of the Council of Ministers of the USSR of May 25, 1961 "On the improvement of learning foreign languages" triggered remarkable changes in the teaching tools. This document proclaimed a course on practical 
orientation in the study of foreign languages which envisaged the formation of the skills to speak, to read and translate special literature. Therefore, specialized textbooks were published with a considerably increased amount of lexical material and professional texts $[1,4$, 17]. The use of such textbooks had a positive effect on the training quality. The head of the department of foreign languages of Kharkiv Agricultural Institute L. Shchehlova cited an example of the effectiveness of training owing to specialized educational books. According to her, students while retelling professionally comprehensible texts from the textbook "Carrot Seed Growing", could not only retell the contents of the texts, but also reported on new methods for sowing carrots and improving sowing techniques developed by employees of their educational institution [16, p. 191].

After the publication of the resolution "On the improvement of learning foreign languages", the departments of foreign languages of agricultural institutes of higher education set about producing their own educational books. The compilation of textbooks, collections of grammar exercises and other text-based teaching tools turned to be an indispensable item in teachers'individual workplans. For instance, in the 1960s in Kharkiv Agricultural Institute teachers of the foreign languages department worked on the creation of the following supporting text-based teaching tools: a RussianEnglish phraseological dictionary; readers in English and German for students of the agronomical faculty and the faculty of land surveyors; a dictionary of agricultural terminology for the students of the faculty of land management engineers [12, p. 15]; collections of text materials for certain specialties: in English for secondyear students on geodesy; in German for the faculty of land management and architecture, in German for firstyear students of the faculty of economics [11, p. 24]. Text-based teaching tools were developed according to the level of students' training, in particular: a manual on the development of oral German language skills on agricultural topics for the first and second year students, a foreign language textbook for students of the correspondence department [16, p.194].

Beginning the 1970s, the department of foreign languages of Kharkiv Institute of Mechanization and Electrification of Agriculture initiated work on compilation of a "dictionary-minimum" to the textbooks used in the educational process $[13, \mathrm{p} .13]$. They prepared a "dictionaryminimum" of verbs, which were most frequently used in technical texts, by grouping words into sections: field husbandry, metallography and repair of agricultural machinery. All explanations to the verbs were coordinated with the relevant departments of the institute: agricultural machinery, repair, metals technology [14, p. 1]. The English language curriculum for the course of mechanization in this institute of higher education included the following texts: "New diesel engine for agricultural machines", "David Brown-950 tractor", "New agricultural machines" $[15$, p. 1].

Teachers of the departments of foreign languages of agricultural institutions of higher education did not cease their productive work on the preparation of text-based teaching aids throughout the period under consideration. As a result, the department of Sumy branch of Kharkiv
Agricultural Institute published English dictionaries for the faculty of mechanization and zoo-engineering faculty in the 1980s. [8, p. 134]. After the branch received an institute status in 1990 and was transformed into Sumy Agrarian Institute, the department of foreign languages of the educational institution prepared a manual in the German language, a German-Russian-Ukrainian dictionary on economics of agriculture, methodological developments of texts for students of the Law department, a compilation of lexical and grammatical texts in English [2, p.194].

Another group of visual teaching tools, known as figurative, also underwent changes during the research period. The group included the objects reflecting material through graphics, painting, photography. As with textbooks, at first there was a severe shortage of specialized image-bearing teaching tools. Therefore, teachers of foreign languages departments tried to use any available visual aids. At Kharkiv Agricultural Institute, students at practical classes worked with reproductions of paintings by such artists as V. Surikov ("The morning of the Streltsy Execution", "Boyarina Morozova", "The Conquest of Siberia by Yermak, etc.), V. Perov ("Troika", "Morning on the River", others.), V. Vasnetsov (" Bogatyrs "," Ivan Tsarevich on the Gray Wolf ",others), A. Savrasov ("The Rooks have come back", others), V. Pukirev ("The Unequal Marriage"). Overall, teachers engaged 17 canvases. Demonstration of these works solved two educational tasks: the skills of oral speech were developed and at the same time students got acquainted with fine arts. Images of the paintings motivated students to make dialogues and stimulated them to ask and answer various questions [16, p.189].

The department of foreign languages of the above mentioned institute of higher education selected pictorial images of both household and agricultural topics. In particular, the following paintings were used: "Harvest time", "City Square", "Park of Culture", "Our City", "On the Collective Farm Garden", "On the Farm", "Spring Plowing", etc. Teachers themselves prepared a certain part of these tools. For example, the plan of action of the department of foreign languages for the 1967-1968 academic year imposed it as an official responsibily for teachers to draw two pictures "On the collective farm garden" and two pictures "On the farm" [11, p. 26]. According to the testimony of L. Shcheglova, head of the foreign language department of Kharkiv Agricultural Institute, the use of figurative learning tools contributed to the development of oral speaking skills, listening comprehension and rendering skills [16, p.190].

During the period under study, the teaching staff of the departments of foreign languages kept on working to variegate visual teaching aids: flashcards, display stands, charts, slides were made to reinforce grammatical material [9, p. 260]. Beginning 1960s, departments of foreign languages of agricultural institutes of higher education got film-viewing devices and series of film strips at their disposal [16, p. 196]. This promoted making certain on-screen stories with questions and dialogues to follow. Such an approach made it possible to encourage students to learn a foreign language and facilitated assimilation of the dialogic vocabulary. 
The 1960s saw a dynamic development of hearing teaching aids. The departments of foreign languages received special teaching devices that gradually increased in number in time. For instance, in 1962 the department of foreign languages of Kharkiv Agricultural Institute owned just one tape recorder [16, p. 196], whereas at the beginning of the 1970 s there was a radio equipped laboratory with 8 tape recorders [10, p 68].

The 1970s were the dawn of language laboratories in agricultural institutes.The departments of foreign languages designed exercises and developed plans for classes in them. For example, in Kharksv Institute of Mechanization and Electrification of Agriculture, all organizational and methodological work on the use of a language laboratory was carried out by September 1971 [14, p. 4]. It was preceded by a discussion of the report "A combination of technical and non-technical teaching tools in the process of teaching foreign languages". During the discussion, teachers paid attention to the peculiarities of using the language laboratory to consolidate special terminology and special vocabulary $[14$, p. 7]. Work in language laboratories enabled creation of an artificial foreign language environment and contributed to the formation of auditory memory, auditory perception, correct pronunciation. In order to create and reinforce the necessary speech patterns (intonation, stress, pronunciation), teachers of foreign languages departments of agrarian institutes of higher education resorted to dictating texts of the textbooks and teaching aids on magnetic tape with further students' listening to this material in language laboratories [9, p. 259]. The disadvantage of this teaching tool was the imperfection of the equipment, which prevented the teacher from controlling and correcting the activities of students.

Visual-auditory and auditory learning tools were introduced in parallel into the practice of the educational process. Thanks to them, the transition from verbal to audiovisual learning began. The value of visual-auditory aids consisted in an increased concentration of attention to educational material and in its special emotional perception. Since the 1990 s there was a shift to the creation of visual-auditory learning tools based on computer technology. Their advantage lies in the possibility of combining video fragments with sound accompaniment and text strings. With the advent of computers, there was no need for imaginative teaching aids and language laboratories. The teacher through the functions "pause', "repeat", "amplification- attenuation", etc. got the opportunity to manage the presentation of educational material at the right pace and at the level accessible for each student.

Conclusions. So, on the basis of sources, we investigated the means of teaching foreign languages in the agricultural institutes of higher education of Ukraine in the second half of the XX century. It is established that in the way of perception of information they can be divided into visual, auditory and visual-auditory.

A gradual transition to specialized textbooks in which texts and terminology from a narrow specialization prevailed was typical of the development of visual means of teaching foreign languages in agrarian institutes of higher education of Ukraine during the period under study. There was a constant growth of educational books compiled by teachers of the departments of foreign languages of agricultural institutes, such as manuals, compilations of grammar exercises, dictionaries, readers and the like. Such visual aids as charts, layouts, and filmstrips got wide distribution and popularity for explaining grammar patterns.

The advent of the teaching tools in the 1960s aimed at the auditory perception of the educational material made it possible to create an artificial foreign language environment for students of the agrarian institutes of higher education of Ukraine. Owing to the language laboratories, the necessary speech patterns were polished, namely: intonation, stress, pronunciation. Visual-auditory and auditory teaching learning tools were simultaneously introduced into the practice of the educational process. During the 70's -80's of the XX century educational films were shown at practical classes, and since the $90 \mathrm{~s}$ a transition to the creation of visual-auditory teaching tools based on computer technology began. These technologies made it possible to combine video fragments with sound accompaniment and text strings, which resulted in replacing verbal education with audiovisual. All the aspects of the research issue extend further. A promising direction is the study of scientific and methodological approaches to the classification of foreign languages teaching tools in agricultural institutes of higher education of Ukraine.

\section{REFERENCES IN ORIGINAL LANGUAGES}

1. Ветрова 3.Д., Турыгина Л.А., Бравина В.А. Учебник французского языка для сельскохозяйственных вузов. Москва: Высшая школа, 1977, 315 с.

2. Звіти кафедр про навчально-методичну роботу за 1998 1999 навчальний рік // Держархів Сумської області, ф.Р.7697, оп.3, спр.327, 233 арк.

3. Эрлих Э., Тримм А., Вольф Л., Бергман Ф. Учебник немецкого языка для высших учебных заведений.Москва: Изд-во ли-ры на ин. языках, 1952, 564 с.

4. Михелевич Е. Е., Бабайлова А. Э., Корольков Ф. В., Троицкая О.А. Учебник немецкого языка для сельскохозяйственных вузов. Москва: Высшая школа, 1985, 399 с.

5. Отчет Белоцерковского сельскохозяйственного института о деятельности за 1953 - 1954 учебный год // Центральний державний архів вищих органів влади та управління України, ф.27, оп.19, спр.1056, 146 арк.

6. Отчет Киевского ветеринарного института за 1953 - 1954 учебный год // Центральний державний архів вищих ор-

ганів влади та управління України, ф.27, оп.19, спр.1060, 174 арк.

7. Отчет Харьковского институту механизации и электрификации сельского хозяйства за 1951 - 1952 учебный год // Центральний державний архів вищих органів влади та управління України. Ф.27. Оп.19. Спр.672. 67 арк.

8. Отчеты кафедр по учебно-методической работе за 1982 1983 учебный год // Держархів Сумської області, ф.Р.7697. Оп.1. Спр.153 146 арк.

9. Отчеты кафедр по учебно-методической работе за 1984 1985 учебный год // Держархів Сумської області. Ф.Р.7697. Оп.1. Спр.286. 269 арк.

10. Отчеты о работе кафедр института за 1969-1970 учебный год // Держархів Харківської області. Ф.Р-1148. Оп.11. Спр.353 Том 1. 149 арк.

11. Планы работы кафедр института на 1967 - 1968 учебный год. // Держархів Харківської області. Ф.Р-1148. Оп.11. Спр.181 39 арк. 
12. Планы работы кафедр института на 1968 - 1969 учебный год. // Держархів Харківської області. Ф.Р-1148. Оп.11. Спр.257. 73 арк.

13. Протоколы заседаний кафедры за 1969 - 1970 учебный год // Держархів Харківської області. Ф.Р-5945. Оп.1. Спр.732. 21 арк.

14. Протоколы заседаний кафедры за 1970 - 1971 учебный год // Держархів Харківської області. Ф.Р-5945. Оп.1. Спр.792. 27 арк.
15. Протоколы заседаний кафедры за 1971 - 1972 учебный год // Держархів Харківської області. Ф.Р-5945. Оп.1. Спр.864. 21 арк.

16. Протоколы и стенограммы заседаний методического ученого совета института, 1962 г. // Держархів Харківської області. Ф.Р-1148. Оп.11. Спр.82. 307 арк.

17. Учебник английского языка для сельскохозяйственных и лесотехнических вузов / Под. ред. И.З.Новоселовой.Москва: Высшая школа, 1975, 302 с.

\section{REFERENCES}

1. Vetrova, Z.D., Turygina L.A., Bravina V.A. French textbook for agricultural institutes. Moscow: Higher School Publishing House, 1977, $315 \mathrm{p}$.

2. Reports of the departments on educational and methodical work for 1998-1999 academic year. //State Archives of Sumy Region, fund P.7697, record 3, file 327, 233 p.

3. Erlikh E., Trimm A., Volf L., Bergman F. Textbook of German for higher educational institutions. Moscow: Publishing house of literature in foreign languages, 1952, $564 \mathrm{p}$.

4. Mikhelevich, Ye. Ye., Babaylova, A. E., Korolkov, F. V. Troitskaya, O. A. Textbook of German for agricultural institutes. Moscow: Higher School Publishing House, 1985, 399 p.

5. Annual activity report of Belotserkovskyi Agricultural Institute for 1953-1954 academic year. // Central State Archives of Superior Bodies of Ukraine, fund 27, record 19, file 1056, $146 \mathrm{p}$.

6. Annual activity report of Kyiv Veterinary Institute for 19531954 academic year. // Central State Archives of Superior Bodies of Ukraine, fund 27, record 19, file 1060, $174 \mathrm{p}$.

7. Annual activity report of Kharkiv Institute of Mechanization and Electrification of Agriculture for 1951-1952 academic year. // Central State Archives of Superior Bodies of Ukraine, fund 27, record 19, file 672, $67 \mathrm{p}$.

8. Reports of the departments on educational-and methodical work for 1982-1983 academic year.//State Archives of Sumy Region, fund P.7697, record 1, file 153, 146 p.

9. Reports of the departments on educational-and methodical work for 1984-1985 academic year. //State Archives of Sumy Region, fund P.7697, record 1, file 286, 269 p.

10. Annual activity reports of the departments of the Institute for 1969-1970 academic year.//State Archives of Kharkiv Region, fund P-1148, record 11, file 353, volume 1, $149 \mathrm{p}$.

11. Work plans for the departments of the Institute for 19671968 academic year. // State Archives of Kharkiv Region, fund P-1148, record 11, file 181, $39 \mathrm{p}$.

12. Work plans for the departments of the Institute for 19681969 academic year. // State Archives of Kharkiv Region, fund P-1148, record 11, file 257, $73 \mathrm{p}$.

13. Minutes of department meetings of 1969-1970 academic year. // State Archives of Kharkiv Region, fund P-5945, record 1 , file $732,21 \mathrm{p}$.

14. Minutes of department meetings of 1970-1971 academic year. // State Archives of Kharkiv Region, fund P-5945, record 1, file 792, $27 \mathrm{p}$.

15. Minutes of department meetings of 1971-1972 academic year. // State Archives of Kharkiv Region, fund P-5945, record 1 , file $864,21 \mathrm{p}$.

16. Minutes and transcripts of meetings of the methodical scientific council of the institute, 1962// State Archives of Kharkiv Region, fund P-1148, record 11, file 82, $307 \mathrm{p}$.

17. English textbook for agricultural and forestry institutes edited by I. Z. Novoselova. Moscow: Higher School Publishing House, 1975,302 p. 